\title{
The Effect of Presenting Anomalous Data on Improving Student's Critical Thinking Ability
}

$\underline{\text { https://doi.org/10.3991/ijet.v14i06.9717 }}$

\author{
Saiful Prayogi $\left.{ }^{(}\right)$, Muhali, Sri Yuliyanti, Muhammad As’ary, Irham Azmi \\ Institut Keguruan dan Ilmu Pendidikan (IKIP), Mataram, Indonesia \\ saifulprayogi@ikipmataram.ac.id \\ Ni Nyoman Sri Putu Verawati \\ Universitas Mataram, Indonesia
}

\begin{abstract}
This study aims to explore the effects of presenting anomalous data on improving student's critical thinking ability. This study is an experimental research conducting on one-group pretest-posttest design. Purposive sampling was used in this study, where one class group was used as a sample of the study, namely 36 students of senior high school at MA Hidayaturrahmah NW Menggala, North Lombok, West Nusa Tenggara, Indonesia. The data of CT ability collected by instrument refer to Ennis-Weir Critical Thinking Essay Test. The data analysis descriptively and statistically were done to process the data of research. Path analysis was used to evaluate the contribution of presenting anomalous data on improving student's critical thinking ability. The results of this study indicate that the presenting anomalous data at initial learning have an effect and contribute on improving student's critical thinking ability. Further reviews are described in this article.
\end{abstract}

Keywords-Anomalous data, critical thinking ability

\section{Introduction}

The process of critical thinking is a cognitive activity to acquire knowledge and produce a new mental representation. It has cannot develop naturally, therefore it must be enriched by various stimuli and diverse environments. One stimulation that can be used in learning, namely the use of conflict cognitive strategies. Conflict cognitive is a condition where there is conflict in the cognitive structure of students [1]. Conflict occurs because of differences in the initial conceptions that students have with their learning experiences [2]. It occurs when students' mental balance is disrupted by experience (referred to as "anomalous data") that is not in accordance with their current understanding [3].

Critical thinking is one of the essential skills that learners have in the 21 st century [4] and has become a major trend and center of learning, even curriculum authorities in some developed countries have included critical thinking skills in their curriculum as learning objectives [5]. For example, the University of California has proclaimed 
"Executive Order 338" in 1983, that is, all learners learn to think critically according to the level of learning and become one of the basic competencies in learning. CT is reasonable and reflective thinking to deciding what to believe or do [6], its detailed description of some characteristic including the process of interpretation, analysis, evaluation, inference, explanation, and self-regulation [7]. Critical thinking is a highlevel thinking area that can be taught continuously, and with the selection of appropriate learning strategies [8].

In practice, most teachers believe that developing critical thinking in learners are importance, however few of them have an idea of how to teach it [8]. Some previous researchers $[9,10,11]$ recommended inquiry activities as a teaching foundation for the purpose to promoting 21 st century skills need, including critical thinking. Through inquiry activities, learners are actively doing their knowledge so that the desired learning outcomes can be achieved [12].

Recently, the intervention of critical thinking processes has been conducted into the inquiry teaching, where the initial phase of learning is presented with conflict cognitive stimulated by the presentation of anomalous data for the purposed to improvement students' critical thinking ability [13]. To strengthen the results obtained, further research is needed to evaluate the effect of presenting anomalous data on improving student's critical thinking ability.

\section{Methodology}

This study is an experimental research with a design of one-group pretest-posttest design [14]. Purposive sampling was used in this study, where one class group was used as a sample of the study, namely 36 students of senior high school at MA Hidayaturrahmah NW Menggala, North Lombok, West Nusa Tenggara, Indonesia. The data of CT ability collected by instrument refer to Ennis-Weir Critical Thinking Essay Test. The data analysis descriptively and statistically were done to process the data of research. Statistical analysis was done in this study (homogeneity test, normality test, $t$ test) to evaluate the effect of presenting anomalous data on improving student's critical thinking ability. Path analysis is used to evaluate the contribution of presenting anomalous data on improving student's critical thinking ability. The contribution is measurable from variable of learning feasibility and learning activities. Statistical data analysis in this study using Statistical Package for Social Science (SPSS) 23.0 software tools.

\section{Results and Discussion}

The results of the data output using the normality and homogeneity tests are $\mathrm{p}$ value (sig.) $(0.200)>\alpha(0.05)$ and $p$ value (sig.) $(0.282)>\alpha(0.05)$ therefore it can be stated that the data are normally distributed and have the same variance (homogeneous). The result of testing the data of students' critical thinking ability using paired t-test shows that $p$ value (sig.) $(0.000)<\alpha(0.05)$, it means that there is improvement of students' critical thinking ability between pretest score and posttest 
score after treatment of presenting anomalous data during learning process. The measurement results of students' critical thinking ability showed that the average score of critical thinking on pretest was -1.42 with not-critical criterion (not critical, if $X \leq 0.8$ ) and posttest of 8.06 with critical criterion (critical, if $5.6<X \leq 8.8$ ), with ngain of 0.72 .

Table 1. The summary of the result of normality and homogeneity test

\begin{tabular}{|c|c|c|c|c|}
\hline \multirow{2}{*}{ Variance } & \multicolumn{2}{|c|}{ Homogenity } & \multicolumn{2}{c|}{ Normality } \\
\cline { 2 - 5 } & Levene's test score & Sig. & N & Sig. \\
\hline Pretest-posttes & 1,422 & 0.282 & 36 & 0.200 \\
\hline
\end{tabular}

Table 2. The summary of the result of statistical test

\begin{tabular}{|c|c|c|c|c|c|c|c|}
\hline \multicolumn{5}{|c|}{ Paired Samples Statistics } & \multicolumn{3}{c|}{ Paired Samples Test } \\
\hline Pair & Mean & Criteria & $\boldsymbol{N}$ & Std. Dev & Pair & Df & Sig. \\
\hline Pretest & $-1,42$ & Not critical & 36 & 1,58 & Pretest-posttest & 35 & 0.000 \\
\hline Posttest & 8,06 & Critical & 36 & 2,37 & & \\
\hline
\end{tabular}

Path analysis is used to evaluate the contribution of presenting anomalous data on improving student's critical thinking ability. The contribution is measurable from variables of learning feasibility and learning activities. The average of learning feasibility (LF) and learning activities (LA) considered of 4.40 and 4.25 , both of which are very good criterion (very good, if LF and LA $\geq 4.21$ ), whereas improvement of critical thinking ability is measured from n-gain before and after learning by 0.72 . The path analysis results are shown in Table 3.

Table 3. Results of path analysis contributing

\begin{tabular}{|c|c|c|c|c|}
\hline & R & R Square & Adjusted R Square & Std. Err. Estimate \\
\hline Presenting of anomalous data & 0.833 & 0.758 & 0.272 & 6,37469 \\
\hline
\end{tabular}

R Square value in Table 3 of 0.758 indicating that contribution of presenting of anomalous data to improvement of students' critical thinking ability of equal to $75.8 \%$. While the rest of $24.2 \%$ is the contribution of other variables as effect of learning. The results of this study generally show that the presenting of anomalous data at the initial learning has a great impact on the improvement of students' critical thinking ability. Presenting anomalous data is very important to be done at the beginning of the learning to generate student motivation in learning. Teacher behavior at the beginning of learning affects the willingness, motivation, and formation of learners' beliefs about what they will learn $[15,16]$. In addition, presenting anomalous data at initial learning is important to invite the learners' interest and ensure that initial knowledge emerges $[17,18,19]$.

Presenting anomalous data on the other hand helps learners to reflect more about their ideas to provide an explanation of the phenomena studied [20]. Giving explanations based on the ideas or learned phenomena is one of the studies and a leading indicator of critical thinking [7,21]. 


\section{Conclusion}

The results of this study indicate that the presenting anomalous data at initial learning have an effect and contribute on improving student's critical thinking ability.

\section{$5 \quad$ References}

[1] Kang, S., Scharmann, L.C., and Noh, T. (2004). Re-examining the role of cognitive conflict in science concept learning. Research in Science Education, 34, 71-96. https://doi.org/10.1023/B:RISE.0000021001.77568.b3

[2] Hewson, D. W., \& Hewson, M. G. (1984). The Role of conceptual conflict in conceptual change and the design of science instruction. Instructional Science, 13, 1-13. https://doi.org/10.1007/BF00051837

[3] Foster, C. (2011). A slippery slope: Resolving cognitive conflict in mechanics. Teaching Mathematics and Its Applications, 30, 216-221. https://doi.org/10.1093/teamat/hrr015

[4] Partnership for 21st Century Skills. (2011). Frame Work for 21st Century Learning. www.p21.org.

[5] Bailin, S. (2002). Critical Thinking and Science Education. Science and Education. 11, 361-375. https://doi.org/10.1023/A:1016042608621

[6] Ennis, R. H. (1991). Critical Thinking: A Streamlined Conception. Teaching Philosophy. 14 (1): 5-24. https://doi.org/10.5840/teachphil19911412

[7] Facione, P. (2011). Critical Thinking. What It Is and Why Its Counts. Measured Reason and The California Academic Press

[8] Prayogi, S., Yuanita, L., \& Wasis. Critical-Inquiry-Based-Learning: Model of Learning to Promote Critical Thinking Ability of Pre-service Teachers. IOP Conf. Series: Journal of Physics, 947: 1-7

[9] Fine, M. \& Desmond, L. 2015. Inquiry-Based Learning: Preparing Young Learners for the Demands of the 21st Century. Educator's Voice VIII: 2-11.

[10] Hamlin, M., \& Wisneski, D. (2012). Supporting the Scientific Thinking and Inquiry of Toddlers and Preschoolers through Play. Young Children 67 (3): 82-88.

[11] Wasis. (2016, Maret). Higher Order Thinking Skills (HOTS): Konsep dan Implementasinya. Seminar Nasional PKPSM IKIP Mataram, Mataram.

[12] Samarapungavan, A., Mantzicopoulos, P., \& Patrick, H. (2008). Learning Science through Inquiry in Kindergarten. Science Education. 92 (5): 868-908 https://doi.org/10.1 $\underline{002 / \text { sce. } 20275}$

[13] Prayogi, S., Yuanita, L. \& Wasis. (2018). Critical Inquiry Based Learning: A Model of Learning to Promote Critical Thinking Among Prospective Teachers of Physic. Journal of Turkish Science Education, 15(1), 43-56.

[14] Fraenkel, J.R., Wallen, N.E., \& Hyun, H.H. (2012). How to Design and Evaluate Research in Education (8th ed.). New York: McGraw-Hill.

[15] Pintrich, P. R. (1999). Motivational Beliefs as Resources for and Constraints on Conceptual Change. In W. Schnotz, S. Vosniadou, dan M. Carretero (Eds.), New perspectives on conceptual change (pp. 33-50). Amsterdam: Pergamon.

[16] Pintrich, P. R., Marx, R. W., \& Boyle, R. A. (1993). Beyond Cold Conceptual Change: The Role of Motivational Beliefs and Classroom Contextual Factors in the Process of Conceptual Change. Review of Educational Research. 63 (2): 167-200. https://doi.org/10. $\underline{3102 / 00346543063002167}$ 
[17] Ambrose, S., \& Lovett, M. (2014). Prior Knowledge is More Than Content: Skills and Beliefs Also Impact Learning. Applying Science of Learning in Education 1 (2): 7-19.

[18] Chinn, C. A., \& Malhotra, B. A. (2002). Children's Responses to Anomalous Scientific Data: How is Conceptual Change Impeded? Journal of Educational Psycholog 94: 327343. https://doi.org/10.1037/0022-0663.94.2.327

[19] Chinn, C. A., \& Brewer, W. F. (1998). An Empirical Text of A Taxonomy of Responses to Anomalous Data in Science. Journal of Research in Science Teaching. 35 (6): 623-654. https://doi.org/10.1002/(SICI) 1098-2736(199808)35:6<623::AID-TEA3>3.0.CO;2-O

[20] Limon, M., \& Carretero, M. (1997). Conceptual Change and Anomalous Data: A Case Study in the Domain of Natural Sciences. European Journal of Psychology of Education. 12 (2): 213-230 https://doi.org/10.1007/BF03173085

[21] Fisher, A. (2003). Critical Thinking An Introduction Anambridge University Press.

\section{Authors}

Saiful Prayogi is lecturer in Physics Education, faculty of Mathematics and Science Education, and member of Central Study of Science and Mathematics Education, Institut Keguruan dan Ilmu Pendidikan (IKIP) Mataram, Indonesia.

Muhali is lecturer in Chemistry Education, faculty of Mathematics and Science Education, and member of Central Study of Science and Mathematics Education, Institut Keguruan dan Ilmu Pendidikan (IKIP) Mataram, Indonesia.

Sri Yuliyanti is lecturer in Mathematic Education, faculty of Mathematics and Science Education

Muhammad Asy'ari is lecturer in Physics Education, faculty of Mathematics and Science Education, Institut Keguruan dan Ilmu Pendidikan (IKIP) Mataram, Indonesia, and member of National Reviewer of Student Creativity Program, Ministry of Research, Technology and Higer Education, Republict of Indonesia.

Irham Azmi member of Central Study of Science and Mathematics Education, Institut Keguruan dan Ilmu Pendidikan (IKIP) Mataram, Indonesia.

Ni Nyoman Sri Putu Verawati is a lecturer in Fundamental Physics course, majoring in Physics Education, Faculty of Teaching and Education, Universitas Mataram, Indonesia.

Article submitted 2018-10-15. Resubmitted 2018-11-17. Final acceptance 2018-11-23. Final version published as submitted by the authors. 